ARTICLE

DOI: $10.1057 /$ s41599-018-0131-7

\title{
Institutional dimensions of the future of philosophy of religion
}

\author{
Lawrence A. Whitney ${ }^{1}$
}

\begin{abstract}
If there is going to be a future for the philosophy of religion, it is going to have to emerge out of and speak into a set of contested disciplinary, institutional, and ideological spaces as their boundaries are in the process of being renegotiated. In the first instance, philosophy of religion has traditionally been located somewhere among the disciplines of philosophy, theology, and religion, but each of these fields is undergoing transformation to which philosophy of religion must respond. At the same time, accreditation standards are requiring humanities disciplines to shift their pedagogical practices even as the commodification of higher education culturally and institutionally calls into question the value of humanistic formation. This paper outlines the points of tension that put pressure on philosophy of religion and suggests ways in which the subdiscipline might understand and locate itself at the heart of liberal and general education in the future.
\end{abstract}

\footnotetext{
${ }^{1}$ Boston University, Boston, MA, USA. Correspondence and requests for materials should be addressed to L.A.W. (email: Iwhitney@bu.edu)
} 


\section{Introduction}

he field of philosophy of religion does not exist in a vacuum. Certainly, philosophy of religion may be understood as a set of questions, methods for answering those questions, and a body of literature made up of earlier philosophers seeking to derive answers to those questions by those methods. At present, as evidenced at least by the existence of this curated collection of perspectives on the topic, the questions themselves and the methods for answering them are increasingly contested, as is the extent of the relevant literature. Merely approaching the disquiet in the field as though it is simply a matter of getting the logic of the discipline sorted out, however, is a serious mistake for failing to take account of the actual disciplinary location of the field, as well as broader shifts underway in the humanities and higher education. Not only is religion one topic among many others in the philosophical arena, so too philosophy of religion has claimants in theology and religion, (i.e., religious studies), even as all three of these fields are undergoing processes of transformation. Those changes, in turn, are being driven not only by internal dynamics but also by broader shifts in the humanities as they face political headwinds, pedagogical reconstruction, and the commodification of higher education at cultural and institutional levels. If philosophy of religion is to have a future, then its course will have to be charted among all of these Scyllae and Charibdi. The good news is that philosophy is perhaps uniquely positioned to get clear about the realities of these hazards, and philosophy of religion has within itself a particular set of resources to harness the wind so as to find its way clear into safe harbor.

\section{Disciplinary pressures}

It would seem obvious that philosophy of religion should find a home in the philosophy department, but this turns out to be far from clear. Until quite recently, philosophy departments in the United States could be distinguished as dominated either by "analytic" or "Continental" approaches to philosophy. The strong view within analytic philosophy, represented by the positivist program, did not have to bother to prove religious claims false as they took religious statements to be meaningless and so unable to be analyzed for their truth or falsity. Strong positions in the Continental camp arrive at a surprisingly similar conclusion, namely that religious statements contribute to the ontology of their interpreters rather than transmitting epistemic content about a religious object. It is hardly clear that the distinction between analytic and Continental forms of philosophy remains relevant, however, especially as the strong versions of each have fallen from favor. The most recent edition of The Philosophical Gourmet Report denies that they are, noting that "certainly there remain differences in styles and methods of philosophical work, but those differences are no longer illuminated by the analytic/ Continental divide" (What the Rankings Mean?-The Philosophical Gourmet Report, 2018). Instead, the report breaks down programs by four specialties-metaphysics and epistemology, philosophy of the sciences and mathematics, theory of value, and history of philosophy - and then lists feminist philosophy, Chinese philosophy, Indian philosophy, and philosophy of race as "other areas." Philosophy of religion is located under the metaphysics and epistemology specialty in the report, as it is in the search function of PhilJobs.org, but no case is made for doing so, and placing it there unnecessarily restricts the range of projects that can and should qualify under the heading of philosophy of religion. Furthermore, philosophy departments may rightly be critiqued and chastised for hunkering down in the bunker of the massively male-dominated Anglo-European philosophical canon, and even insisting that nothing beyond that canon could possibly be considered real philosophy (Van Norden, 2017). All too often, what passes for philosophy of religion is in the vanguard of this regressive charge.

If philosophy of religion is not to be found in the philosophy department, then perhaps it is to be found in the religion department. Indeed, quite a few philosophers of religion have been located in religion departments, but increasingly with a degree of suspicion from members of the department who employ other approaches in investigating the religious domain. Some of this suspicion arises from the concern that philosophy of religion is sneaking confessional theology through the back door into what is supposed to be an objective approach to religion. In a related vein, philosophy of religion appears to be too normative, evaluating which beliefs are rational and which are not, in a field that purports to be descriptive in nature. Insofar as philosophy of religion is indeed normative, this would seem to place it in the camp of theological studies as opposed to religious studies more broadly (Neville, 1993, p. 191). Also, as religious studies increasingly concerns itself with religious practice and performance, social scientific and historical approaches have come to dominate religion departments, glaring skeptically at philosophy of religion for focusing on out-of-vogue religious beliefs. The allergy to beliefs comes largely from associating a focus on belief with a bias toward Protestantized religious forms, thereby neglecting authentically religious expression in other traditions and in everyday life. These concerns express "a strategic preference for defining religious studies in league with history and the human sciences rather than with the humanities, thereby simultaneously consolidating an intelligible place for religious studies in the academy and disentangling the academic study of religion from its theological and often Christian roots" (Wildman, 2010, p. 18).

The other place that philosophy of religion might register in the disciplinary matrix of the academy is in theology departments, divinity schools, or seminaries. In these cases, philosophy of religion generally appears in two guises. The first is as a form of natural theology, distinguishing itself from other forms of theology by relying solely on reason, and perhaps natural evidence, instead of any form of divine revelation in the form of scripture or religious experience (Manning et al., 2013, pt. III). The second is in the mode of philosophical theology, which employs philosophical methods and concepts to evaluate and sometimes reconstruct theological doctrines (Meister and Taliaferro, 2016). In neither case is it necessary that philosophy of religion locate itself within a specific religious tradition or identify itself with one or another tradition, although plenty of philosophers of religion do so identify, often enough with a relatively high degree of ambivalence about doing so. In both cases, philosophy of religion is subject to critique from religious communities for claiming to know too much, for presuming the rational accessibility of its object apart from revelation, and for being superficial with respect to the depth, breadth, and complexity of religious traditions in their totality (Wildman, 2010, pp. 29-30). Moreover, theological preferences of late have been trending away from either of these approaches toward more contextual, communal, and liberative methodologies.

In addition to the pressures on philosophy of religion within each of the philosophical, religious, and theological realms respectively, the viability of philosophy of religion in each realm adds to the pressures exerted on the field in the others. At one level, this takes the form of, "you don't belong here, you belong over there," resulting in a game of musical chairs where philosophy of religion must eventually be left standing alone. At the same time, the viability of philosophy of religion in theological contexts only exacerbates suspicions in philosophy and religion 
departments that confessional theology is being snuck in the back door. The association of philosophy departments with skepticism toward religion and narrow concern with the ideas of dead white men exacerbates the theological trend away from philosophical approaches as the theological academy diversifies rapidly (Diversity in Theological Education, 2003, pp. 20-23; Transitions, 2017 , pp. 8-9). At the same time, unwillingness of philosophy to address itself to and be addressed by nonwestern canons triggers allergies to parochialism in religion departments. Meanwhile, religion departments scorning normative work drives a wedge between them and theology, while the turn to practice makes philosophy skeptical of the conceptual rigor of religious studies. Ironically, all of this is taking place while a number of philosophers of religion, including emerging scholars who are tentative about adopting that nomenclature for fear of getting trapped in the disciplinary melee, are actually seeking to pitch a much broader tent for the field (Clayton, 2006; Neville, 2009, 2013, 2014, 2015; Smid, 2010; Wildman, 2010; Yong, 2012; Knepper, 2013; Dawes, 2016).

\section{Humanities in higher education}

Philosophy of religion belongs to the set of domains that make up the humanities within the broad scope of higher education, and so is subject to pressures being exerted on the humanities amidst the shifting landscapes of higher education. Politically, the humanities are under pressure for at least two reasons: a perceived lack of practical utility, and liberal bias. Increasingly, parents, students, and politicians perceive a broad liberal education, and particularly the humanistic elements thereof, to have little if anything to do with developing the skills to become marketable for the high-end jobs that would justify the expense of a college degree. The fact that some of the highest paying companies proactively recruit students who specialized in the humanities seems not to be making much of a dent in that perception (Litt, 2017; Strauss, 2017; Anders, 2017; Stross, 2017). At the same time, conservative politicians and pundits make a great deal of hay about liberal bias in the academy (Kamisar, 2016). While there is empirical evidence that faculty members do tend to lean left to a certain extent, and in humanities and social science disciplines especially so (Gross, 2013; Gross and Simmons, 2014; Shields and Dunn 2016), it is not at all clear that the personal political views of faculty impacts classroom instruction or evaluation (Gross, 2016). Nevertheless, political rhetoric fuels the perception that humanities disciplines are primarily loci for political indoctrination to the extent that even at least one rather progressive columnist has issued a call for affirmative action for conservatives in the academy (Kristof, 2016). Taken together, the practical utility problem and the liberal bias problem put the pressure on humanities disciplines to recruit and retain students, without whom the viability of humanities departments becomes questionable (Prose, 2017; Sommerhauser, 2018; Tworek, 2013).

These same political headwinds, among others, are causing accrediting bodies to reformulate their standards such that institutions are required to provide evidence of student learning, which in turn is requiring faculty to rethink their pedagogy (Accreditation Resources, 2012). This rethinking is frequently framed as a fundamental shift from a focus on teaching methods, strategies, and practices to a focus on how students are best able to learn. Faculty are asked to identify specific learning objectives for their courses overall and for individual class meetings, and then to utilize various learning activities in order to achieve these objectives, which in turn generate feedback and become available for assessment (Fink, 2005; Wiggins and McTighe, 2005; Kuh et al., 2014; Jankowski and Marshall, 2017). While it is certainly worthwhile for instructors in the humanities to pay attention to and learn from the most recent research on teaching and learning, and without trying to claim that all teaching in the humanities in fact achieves its ideals (Bok, 2009), there are two challenges to this approach for the self-understanding of the humanities. Both challenges have to do with the fact that the approach assumes that the instructor knows a priori what students can and should be learning by engaging the content of the course. The first challenge is that this assumption foregrounds and centralizes the role of the instructor instead of making the content itself central, with the instructor and the students, in various ways, orbiting (Fiorenza, 2009; Taranto and Dettmar, 2015). The second challenge is the very assumption that it is possible to know a priori what can and should be learned, which seems to in turn assume that learning is primarily a process of information somehow distinct from formation, reformation, and transformation (Freire, 2006; Glennon et al., 2011). Moreover, learning in the humanities cannot necessarily be expected to take place during the period of a particular course; humanistic learning is cumulative as literatures are engaged and then brought into conversation with other literatures in other courses. This makes assessment particularly difficult in the humanities because not everything meaningful is measureable.

These political discourses and pedagogical redevelopments also interact with a third process inducing pressure in higher education: commodification. The notion of commodification refers to treating goods, services, people, and ideas as objects of trade for exchange in a marketplace. With respect to higher education, commodification refers to the capitalization of knowledge for profit (Slaughter and Rhoades, 2004; Chomsky, 2014), the commercialization of college athletics, degrees, and research (Bok, 2008), and declines in actual learning as the degree functions increasingly as a club card rather than a hallmark of achievement (Molesworth et al., 2009; Arum and Roksa, 2011). In spite of paeans to faculty governance, the commodification of higher education is characterized by a decline in faculty involvement and control of education in favor of professional administrators operating primarily under the rubric of education as training for the workforce (Tuchman, 2009; Ginsberg, 2011; Asher, 2018). The increasing cost of higher education in part drives the trendexacerbated since the 2008 recession and subsequent economic stagnation-for faculty, staff, and students to think of students as customers and colleges and universities as service providers (Eagle and Brennan, 2007; Love, 2008; Tuchman, 2011; Schwartzman, 2013). The humanities are thus put in the position of having to justify themselves as providing valuable training for an emerging workforce, articulable in terms of competencies. Rather than the broad understanding of the role of education in the humanities and liberal arts as promoting self-understanding and a vision for a good life (Ferrall, 2011; DeNicola, 2012; Marenne, 2016), commodified education is reduced to preparation for a job or career (Deresiewicz, 2014; Berrett, 2015).

\section{Some good news}

Despite the disciplinary and institutional pressures being exerted on philosophy of religion, there are at least two areas of good news for the field. First, a renewed focus on and reconfiguration of general education within collegiate curricula may prove particularly amenable to the interests, inquiries, and modes of thought in philosophy of religion. Led by the Association of American Colleges and Universities, many institutions are appropriating the outcomes of their Liberal Education and America's Promise (LEAP) Initiative (Association of American Colleges \& Universities, 2011). The vision they articulate is that liberal education is a necessity for all students regardless of major, and so is the hallmark of the general education all students 
receive in their undergraduate programs (Nussbaum, 2010; What Is a 21st Century Liberal Education?, 2014; Delbanco, 2014). This sort of general education is vastly different from the distribution requirements or core curricula of introductory courses among liberal arts disciplines that undergraduates would frequently complete in the first 2 years of college (Menand, 2010, chap. 1). Instead, in this model, introductory, advanced, and integrative courses pervade the collegiate experience. Liberal education seeks to equip students with "knowledge of human cultures and the physical and natural world," intellectual and practical skills in analysis and communication, capacity to live into personal and social responsibility, and the ability to integrate, synthesize, and apply learning in general and in their specialization (Association of American Colleges and Universities, 2011, p. 7; Ferren and Paris, 2015). Rather than ticking off a certain number of courses in each of several categories such as mathematics, natural sciences, social sciences, humanities, languages, etc., general education programs under the new model invite students to chart unique trajectories through course offerings that cultivate particular skills and habits of mind in integrative ways. The goal is for students to become adept at identifying and implementing a range of tools to address complex challenges and to be able to envision novel and creative approaches to problems where methods for addressing them are not obvious (Roth, 2014; Gaston, 2015).

Moreover, philosophy of religion is uniquely poised to accompany students in addressing, with scholarly credibility and academic rigor, the big questions so many are earnestly asking and that renewed general education curricula in part seek to address. On one hand, students come to school with live questions about meaning, purpose, faith, morality, how to be at home in the universe, and how to relate to authority (Parks, 2000, 2011). On the other, higher education is awakening to these needs for holistic education-intellectual, moral, emotional, and spiritual-at least in part because understanding education to be more than the transaction of information justifies traditional residential models (Astin et al., 2010; Jacobsen and Jacobsen, 2012; Brooks, 2015a). It may seem like claiming that philosophy of religion is inherently oriented toward addressing precisely these needs is belied by increasing claims among college students to be "spiritual but not religious" and identifying as religiously disaffiliated (Lipka, 2015, 2016; Smith and Cooperman, 2016; Lipka and Gecewicz, 2017). To the contrary, disaffection from organized religion does not equate with abandoning consideration of issues of transcendence, human nature, community, the afterlife, and other central topics in philosophy of religion (Mercadante, 2014). Furthermore, those who do remain affiliated with religious traditions and organizations cannot necessarily be assumed to have beliefs and practices that are entirely in line with the stated orthodoxies of the groups with whom they affiliate (Berthrong, 1999; Ammerman, 2013). Even those who do consider themselves in some sense orthodox with respect to one tradition or another must inevitably grapple with doubt (Berger and Zijderveld, 2009), and indeed will benefit themselves, their communities, and the world in doing so (Carse, 2008). Students in each and all of these situations would benefit from tutelage to cultivate clear and rigorous thinking about these matters, in conversation with those who have struggled with the same issues before them, which philosophy of religion is uniquely capable of providing.

\section{Whither philosophy of religion?}

The cottage industry of envisioning some sort of future for the philosophy of religion has almost uniformly and arbitrarily constrained its imagination to the locus of disciplinary reconfiguration and stylistics (Goodchild, 2002; Trakakis, 2008, 2013;
Crisp and Rea, 2009; Smith and Whistler, 2010; Wildman, 2010; Hewitt, 2012; Rennie, 2012a, b; Schilbrack, 2012, 2014a, b; Strenski, 2012a, b; Knepper, 2013, 2014; Crockett, Putt and Robbins, 2014; Irvine, 2014; McLachlan, 2014; Simmons, 2014; Lewis, 2015; Onishi, 2017; Draper and Schellenberg, 2018; Kanaris, 2018). This imaginative constraint reflects these projects being caught in the ongoing tug of war among anti-disciplinarity, interdisciplinarity, and postdisciplinarity, which may have value in its own right for the humanities broadly (Menand, 2010, chaps 2.5-6), but could easily lead to ruin for philosophy of religion due to its departmental dislocation. Thomas D. Carroll seems to be alone, until now, in recognizing not only the perceived irrelevance of philosophy of religion in the academy, but also the immediate need to make the case for its relevance attending to the terms of relevance actually at play (Carroll, 2016). A central purpose of this article is to provide philosophers of religion entre into the literatures, concepts, and terms of debate regarding relevance in higher education, which Carroll does not adequately address.

What might a relevant philosophy of religion look like? First and foremost, philosophy of religion will indeed have to get rid of its parochialism and bias, not primarily for the sake of relevance, but for the sake of scholarly credibility (Wildman, 2010; Draper and Nichols, 2013; Knepper, 2013; Schilbrack, 2014a). Moreover, philosophers of religion will have to walk a knife edge to resist their training to be narrow and focused in order to address nonspecialist general audiences (Menand, 2010, chap. Conclusion), without sacrificing precision, rigor, and clarity of thought. This will involve engaging literatures far beyond the Western canon (Van Norden, 2017), and topics beyond metaphysics and epistemology (Brunsveld and Trigg, 2011); notably, the first will inevitably lead to the second (Neville, 2016, 2018; Angle and Tiwald, 2017). Systemically, philosophers of religion will need to learn to articulate their programs and pedagogy in terms of the goal of liberal and holistic education to equip students to thrive in their personal, professional, and civic lives by engaging with complexity, diversity, and change (e.g., Boston University Task Force on General Education, 2017). For those left standing in the game of musical chairs amongst philosophy, theology, and religion, this may mean immigrating in order to make a new home in a department of writing, a core curriculum program, or a general education initiative. Finally, philosophers of religion will have to come to terms with the normativity of their discipline and get over their fear that prescription might inhibit individual choice in order to shift into an applied modality such that the outcomes of inquiries are applicable in everyday life (Brooks, 2015a, b). Too often philosophy of religion is reducible to scratching the personal itches of the philosopher in question. The future of the discipline depends on turning outward to equip others to scratch their own itches and on philosophically addressing pressing issues in society and culture. Doing so will require that philosophers of religion participate as partners in the institutional dynamics of the academy in which they reside.

Received: 12 April 2018 Accepted: 21 May 2018

Published online: 12 June 2018

\section{References}

Accreditation Resources (2012) National Institute for Learning Outcomes Assessment. http://www.learningoutcomeassessment.org/Accreditation1.htm. Accessed 6 Apr 2018

Ammerman NT (2013) Sacred Stories, Spiritual Tribes: Finding Religion in Everyday Life. Oxford University Press: New York

Anders G (2017) You Can Do Anything: The Surprising Power of a 'Useless' Liberal Arts Education. Little, Brown and Company: New York 
Angle SC, Tiwald J (2017) Neo-Confucianism: A Philosophical Introduction. John Wiley \& Sons: Malden, MA

Arum R, Roksa J (2011) Academically Adrift: Limited Learning on College Campuses. University of Chicago Press: Chicago: IL

Asher L (2018, 8 April) How Ed Schools Became a Menace. The Chronicle of Higher Education. http://www.chronicle.com/article/How-Ed-SchoolsBecame-a-Menace/243062 Accessed 10 Apr 2018

Association of American Colleges \& Universities (2011) The LEAP vision for learning: outcomes, practices, impact, and employers' views. Association of American Colleges and Universities, Washington, DC, https://www.aacu.org/ sites/default/files/files/publications/LEAP_Vision_Summary.pdf. Accessed 10 April 2018

Astin AW, Astin HS, Lindholm JA (2010) Cultivating the Spirit: How College Can Enhance Students' Inner Lives. John Wiley \& Sons: Malden, MA

Berger P, Zijderveld, A (2009) In Praise of Doubt: How to Have Convictions Without Becoming a Fanatic. Harper Collins: New York, NY

Berrett D (2015, 26 January) The Day the Purpose of College Changed. The Chronicle of Higher Education. http://www.chronicle.com/article/The-Daythe-Purpose-of-College/151359. Accessed 10 Apr 2018

Berthrong JH (1999) The Divine Deli: Religious Identity in the North American Cultural Mosaic. Orbis Books: Maryknoll, NY

Bok D (2008) Universities in the Marketplace: The Commercialization of Higher Education. Princeton University Press: Princeton, NJ

Bok D (2009) Our Underachieving Colleges: A Candid Look at How Much Students Learn and Why They Should be Learning More. Princeton University Press: Princeton, NJ

Boston University Task Force on General Education (2017) The Hub's six capacities, constitutive areas, and the signature cross-college challenge. http:// www.bu.edu/gened/practical-guide-for-faculty/six-capacities/. Accessed 12 Apr 2018

Brooks D (2015a, 6 October) The Big University, The New York Times. https:// www.nytimes.com/2015/10/06/opinion/david-brooks-the-big-university. html. Accessed 10 Apr 2018

Brooks D (2015b) The Road to Character. Random House: New York, NY

Brunsveld N, Trigg R (eds) (2011) Religion in the Public Sphere: Proceedings of the 2010 Conference of the European Society for Philosophy of Religion. Ars Disputandi: Utrecht, (Ars Disputandi Supplement series, 5)

Carroll TD (2016) The problem of relevance and the future of philosophy of religion. Metaphilosophy 47(1): 39-58. https://doi.org/10.1111/meta.12168.

Carse JP (2008) The Religious Case Against Belief. Penguin: New York, NY

Chomsky N (2014) How America's great university system is being destroyed. Adjunct Faculty Association of the United Steelworkers, Pittsburgh. http:// www.ora.tv/homepage/2016/8/29/1. Accessed 10 Apr 2018

Clayton J (2006) Religions, Reasons and Gods: Essays in Cross-Cultural Philosophy of Religion. Cambridge University Press: Cambridge, UK

Crisp OD, Rea MC (2009) Analytic Theology: New Essays in the Philosophy of Theology. Oxford University Press: New York, NY

Crockett C, Putt BK, Robbins JW (2014) The Future of Continental Philosophy of Religion. Indiana University Press: Bloomington, IN

Dawes GW (2016) Religion, Philosophy and Knowledge. Springer: Cham, Switzerland

Delbanco A (2014) College: What It Was, Is, and Should Be. Princeton University Press: Princeton, NJ

DeNicola DR (2012) Learning to Flourish: A Philosophical Exploration of Liberal Education. Bloomsbury: New York, NY

Deresiewicz W (2014) Excellent Sheep: The Miseducation of the American Elite and the Way to a Meaningful Life. Simon and Schuster: New York, NY

Diversity in Theological Education (2003) Association of Theological Schools. http://www.ats.edu/uploads/resources/publications-presentations/ documents/diversity-in-theological-education-folio.pdf. Accessed 16 May 2018

Draper P, Nichols R (2013) Diagnosing Bias in Philosophy of Religion. Monist 96 (3): 420-446. http://www.jstor.org/stable/42751260

Draper P, Schellenberg JL (2018) Renewing Philosophy of Religion: Exploratory Essays. Oxford University Press: New York, NY

Eagle L, Brennan R (2007) Are students customers? TQM and marketing perspectives. Quality Assurance in Education 15(1): 44-60. https://doi.org/ $10.1108 / 09684880710723025$

Ferrall VE (2011) Liberal Arts at the Brink. Harvard University Press: Cambridge, MA

Ferren AS, Paris DC (2015) Faculty Leadership for Integrative Liberal Learning. Association of American Colleges \& Universities: Washington, DC

Fink LD (2005) Integrated Course Design. The Idea Center, Manhattan, KS, http:// www.ideaedu.org/Portals/0/Uploads/Documents/IDEA\%20Papers/IDEA\% 20Papers/Idea_Paper_42.pdf. Accessed: 6 Apr 2018

Fiorenza ES (2009) Democratizing Biblical Studies: Toward an Emancipatory Educational Space. Westminster John Knox Press: Louisville, KY
Freire P (2006) The banking model of education. In: Provenzo EF (ed) Critical Issues in Education: An Anthology of Readings. Sage: Thousand Oaks, CA, pp. 106-119

Gaston PL (2015) General Education Transformed: How We Can, Why We Must. Association of American Colleges and Universities: Washington, DC

Ginsberg B (2011) The Fall of the Faculty: The Rise of the All-Administrative University and Why It Matters. Oxford University Press: New York, NY

Glennon F et al. (2011) Formation in the Classroom. Teaching Theology \& Religion 14(4): 357-381. https://doi.org/10.1111/j.1467-9647.2011.00740.x

Goodchild P (2002) Rethinking Philosophy of Religion: Approaches from Continental Philosophy. Fordham University Press: New York, NY

Gross N (2013) Why Are Professors Liberal and Why Do Conservatives Care? Harvard University Press: Cambridge, MA

Gross N (2016, 20 May) Professors are overwhelmingly liberal. Do universities need to change hiring practices?, Los Angeles Times. http://www.latimes.com/ opinion/op-ed/la-oe-gross-academia-conservatives-hiring-20160520-snapstory.html. Accessed 6 Apr 2018

Gross N, Simmons S (2014) Professors and Their Politics. Johns Hopkins University Press: Baltimore, MD

Hewitt M (2012) Affective and cognitive dimensions of religious experience: toward a conceptual/theoretical integrative perspective. Studies in Religion/ Sciences Religieuses 41(1): 33-45. https://doi.org/10.1177/0008429811430056.

Irvine AB (2014) On Kevin Schilbrack's Philosophy and the Study of Religions: A Manifesto. Sophia 53(3): 367-372. https://doi.org/10.1007/s11841-014-0432-2

Jacobsen RH, Jacobsen D (2012) No Longer Invisible: Religion in University Education. Oxford University Press: New York, NY

Jankowski NA, Marshall DW (2017) Degrees that Matter: Moving Higher Education to a Learning Systems Paradigm. Stylus Publishing: Sterling, VA

Kamisar B (2016, 19 July) Pollster Frank Luntz: 'GOP has "lost" the millennial generation', The Hill. http://thehill.com/blogs/ballot-box/polls/288321pollster-frank-luntz-millennial-generation-lost-for-gop. Accessed 6 Apr 2018

Kanaris J (2018) Reconfigurations of Philosophy of Religion: A Possible Future. SUNY Press: Albany, NY

Knepper TD (2013) The Ends of Philosophy of Religion: Terminus and Telos. Palgrave Macmillan: New York, NY

Knepper TD (2014) The end of philosophy of religion? Journal of the American Academy of Religion 82(1): 120-149. https://doi.org/10.1093/jaarel/lft072

Kristof N (2016, 10 December) The dangers of echo chambers on campus, The New York Times. https://www.nytimes.com/2016/12/10/opinion/sunday/thedangers-of-echo-chambers-on-campus.html. Accessed 6 Apr 2018

Kuh GD et al. (2014) Using Evidence of Student Learning to Improve Higher Education. John Wiley \& Sons: Malden, MA

Lewis TA (2015) Why Philosophy Matters for the Study of Religion-and Vice Versa. Oxford University Press: New York, NY

Lipka M (2015, 12 May) Millennials increasingly are driving growth of "nones", Pew Research Center. http://www.pewresearch.org/fact-tank/2015/05/12/ millennials-increasingly-are-driving-growth-of-nones/. Accessed 10 Apr 2018

Lipka M (2016, 24 August) Why America's "nones" left religion behind, Pew Research Center. http://www.pewresearch.org/fact-tank/2016/08/24/whyamericas-nones-left-religion-behind/ Accessed 10 Apr 2018

Lipka M, Gecewicz C (2017, 6 September) More Americans now say they're spiritual but not religious, Pew Research Center, http://www.pewresearch.org/ fact-tank/2017/09/06/more-americans-now-say-theyre-spiritual-but-notreligious/. Accessed 10 Apr 2018

Litt M (2017, 15 July) Why this tech CEO keeps hiring humanities majors, Fast Company. https://www.fastcompany.com/40440952/why-this-tech-ceokeeps-hiring-humanities-majors. Accessed 6 Apr 2018

Love K (2008) Higher education, pedagogy and the "customerisation" of teaching and learning. Journal of Philosophy of Education 42(1): 15-34. https://doi.org/ 10.1111/j.1467-9752.2008.00600.x

Manning RR, Brooke JH, Watts F (2013) The Oxford Handbook of Natural Theology. Oxford University Press: Oxford, UK

Marenne ET de (2016) The Case for the Humanities: Pedagogy, Polity, Interdisciplinarity. Rowman \& Littlefield: Lanham, MD

McLachlan J (2014) Kevin Schilbrack on defining religion and the field of the study of religions. Sophia 53(3): 379-382. https://doi.org/10.1007/s11841-014-0445$\mathrm{x}$

Meister C, Taliaferro C (2016) Contemporary Philosophical Theology. Routledge: New York, NY

Menand L (2010) The Marketplace of Ideas. W. W. Norton \& Company: New York, NY

Mercadante LA (2014) Belief Without Borders: Inside the Minds of the Spiritual But Not Religious. Oxford University Press: New York, NY

Molesworth M, Nixon E, Scullion R (2009) Having, being and higher education: the marketisation of the university and the transformation of the student into consumer. Teaching in Higher Education 14(3): 277-287. https://doi.org/ $10.1080 / 13562510902898841$ 
Neville RC (1993) Religious studies and theological studies. Journal of the American Academy of Religion LXI(2):185-200. https://doi.org/10.1093/jaarel/ LXI.2.185

Neville RC (2009) Realism in Religion: A Pragmatist's Perspective. SUNY Press: Albany, NY

Neville RC (2013) Ultimates: Philosophical Theology, Vol 1. SUNY Press: Albany, $\mathrm{NY}$

Neville RC (2014) Existence: Philosophical Theology, Vol 2. SUNY Press: Albany, $\mathrm{NY}$

Neville RC (2015) Religion: Philosophical Theology, Vol 3. SUNY Press: Albany, NY

Neville RC (2016) The Good is One, Its Manifestations Many: Confucian Essays on Metaphysics, Morals, Rituals, Institutions, and Genders. SUNY Press: Albany, NY

Neville RC (2018) Defining Religion: Essays in Philosophy of Religion. SUNY Press: Albany, NY

Nussbaum MC (2010) Not for Profit: Why Democracy Needs the Humanities. Princeton University Press: Princeton, NJ

Onishi BB (2017) The beginning, not the end: on continental philosophy of religion and religious studies. Journal of the American Academy of Religion 85(1): 1-30. https://doi.org/10.1093/jaarel/lfw032

Parks SD (2000) Big Questions, Worthy Dreams: Mentoring Young Adults in Their Search for Meaning, Purpose, and Faith. Wiley: San Francisco, CA

Parks SD (2011) Big Questions, Worthy Dreams: Mentoring Emerging Adults in Their Search for Meaning, Purpose, and Faith. John Wiley \& Sons: San Francisco, CA

Prose F (2017, 12 May) Humanities teach students to think. Where would we be without them?, The Guardian. Available at: http://www.theguardian.com/ commentisfree/2017/may/12/humanities-students-budget-cuts-universitysuny. Accessed 6 Apr 2018

Rennie B (2012a) New directions for philosophy of religion: introduction and acknowledgements. Studies in Religion/Sciences Religieuses 41(1): 3-4. https:// doi.org/10.1177/0008429811430053

Rennie B (2012b) The history (and philosophy) of religions. Studies in Religion/ Sciences Religieuses 41(1): 24-32. https://doi.org/10.1177/0008429811430055

Roth MS (2014) Beyond the University: Why Liberal Education Matters. Yale University Press: New Haven, CT

Schilbrack K (2012) New directions for philosophy of religion: four proposals. Studies in Religion/Sciences Religieuses 41(1): 46-56. https://doi.org/10.1177/ 0008429811430058

Schilbrack K (2014a) Philosophy and the Study of Religions: A Manifesto. John Wiley \& Sons: Malden, MA

Schilbrack K (2014b) The future of philosophy of religion. Sophia 53(3): 383-388. https://doi.org/10.1007/s11841-014-0433-1

Schwartzman R (2013) Consequences of commodifying education. Academic Exchange Quarterly 17(3): 41-46

Shields JA, Dunn Sr. JM (2016) Passing on the Right: Conservative Professors in the Progressive University. Oxford University Press: New York, NY

Simmons JA (2014) Toward an expansive phenomenology of religious existence. Sophia 53(3): 373-377. https://doi.org/10.1007/s11841-014-0444-y

Slaughter S, Rhoades G (2004) Academic Capitalism and the New Economy: Markets, State, and Higher Education. Johns Hopkins University Press: Baltimore, MD

Smid RW (2010) Methodologies of Comparative Philosophy: The Pragmatist and Process Traditions. SUNY Press: Albany, NY

Smith AP, Whistler D (2010) After the Postsecular and the Postmodern: New Essays in Continental Philosophy of Religion. Cambridge Scholars Publishing: Newcastle upon Tyne, UK

Smith GA, Cooperman A (2016, 14 September) The factors driving the growth of religious "nones" in the U.S., Pew Research Center http://www.pewresearch. org/fact-tank/2016/09/14/the-factors-driving-the-growth-of-religious-nonesin-the-u-s/. Accessed 10 Apr 2018

Sommerhauser M (2018) Controversy follows UW-Stevens Point decision to cut humanities programs, Wisconsin State Journal. http://host.madison.com/ news/local/education/university/controversy-follows-uw-stevens-pointdecision-to-cut-humanities-programs/article_e9f59317-6d91-545a-a95ec64befb44447.html Accessed 6 Apr 2018

Strauss V (2017, 20 December) The surprising thing Google learned about its employees-and what it means for today's students, Washington Post. https:// www.washingtonpost.com/news/answer-sheet/wp/2017/12/20/thesurprising-thing-google-learned-about-its-employees-and-what-it-meansfor-todays-students/. Accessed 6 Apr 2018
Strenski I (2012a) Final replies to Kevin Schilbrack's response. Studies in Religion Sciences Religieuses 41(1): 57-67. https://doi.org/10.1177/0008429811430059

Strenski I (2012b) Philosophy of (lived) religion. Studies in Religion/Sciences Religieuses 41(1): 5-11. https://doi.org/10.1177/0008429811430052

Stross R (2017) A Practical Education: Why Liberal Arts Majors Make Great Employees. Redwood Press: Stanford, CA

Taranto J, Dettmar KJh (2015, 14 September) The secret of good humanities teaching, The Chronicle of Higher Education. http://www.chronicle.com/ article/The-Secret-of-Good-Humanities/233097. Accessed 6 Apr 2018

Trakakis N (2008) The End of Philosophy of Religion. A\&C Black: New York, NY

Trakakis N (2013) Truth, or the futures of philosophy of religion. International Journal of Philosophy and Theology 74(5): 366-390. https://doi.org/10.1080/ 21692327.2014.899156.

Transitions (2017) Annual Report. Association of Theological Schools, Pittsburgh, PA, p 44, https://www.ats.edu/uploads/resources/publications-presentations/ documents/2017-Annual-Report.pdf. Accessed 16 May 2018

Tuchman G (2009) Wannabe U: Inside the Corporate University. University of Chicago Press: Chicago, IL

Tuchman G (2011) The unintended decentering of teaching and learning. Society 48(3): 216-219. https://doi.org/10.1007/s12115-011-9420-0

Tworek H (2013, 18 December) The real reason the humanities are "in crisis", The Atlantic. https:/www.theatlantic.com/education/archive/2013/12/the-realreason-the-humanities-are-in-crisis/282441/. Accessed 6 Apr 2018

Van Norden BW (2017) Taking Back Philosophy: A Multicultural Manifesto. Columbia University Press: New York, NY

What is a 21st century liberal education? (2014) Association of American Colleges and Universities. https://www.aacu.org/leap/what-is-a-liberal-education. Accessed 10 Apr 2018

What the rankings mean?-The philosophical gourmet report (2018) http:// 34.239.13.205/index.php/philosophy-of-language/what-the-rankings-mean/. Accessed 26 Mar 2018

Wiggins G, McTighe J (2005) Understanding by Design. Association for Supervision and Curriculum Development: Alexandria, VA

Wildman WJ (2010) Religious Philosophy as Multidisciplinary Comparative Inquiry: Envisioning a Future for the Philosophy of Religion. SUNY Press: Albany, NY

Yong A (2012) The Cosmic Breath: Spirit and Nature in the Christianity-BuddhismScience Trialogue. BRILL: Boston, MA

\section{Data availability}

Data sharing not applicable to this article as no datasets were generated or analyzed during the current study.

\section{Additional information}

Competing interests: The author declares no competing interests.

Reprints and permission information is available online at http://www.nature.com/ reprints

Publisher's note: Springer Nature remains neutral with regard to jurisdictional claims in published maps and institutional affiliations.

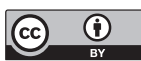

Open Access This article is licensed under a Creative Commons Attribution 4.0 International License, which permits use, sharing, adaptation, distribution and reproduction in any medium or format, as long as you give appropriate credit to the original author(s) and the source, provide a link to the Creative Commons license, and indicate if changes were made. The images or other third party material in this article are included in the article's Creative Commons license, unles indicated otherwise in a credit line to the material. If material is not included in the article's Creative Commons license and your intended use is not permitted by statutory regulation or exceeds the permitted use, you will need to obtain permission directly from the copyright holder. To view a copy of this license, visit http://creativecommons.org/ licenses/by/4.0/

(C) The Author(s) 2018 